\begin{tabular}{c|cc|}
\hline $\begin{array}{c}\text { ADVANCE RESEARCH JOURNAL OF SOCIAL SCIENCE } \\
\text { ReVIEW } \\
\text { ARTICLE }\end{array}$ & $\begin{array}{c}\text { Volume } 7 \text { | Issue 2 | December, 2016 | 252-262 } \\
\text { e ISSN-2231-6418 }\end{array}$ \\
\hline DOI: 10.15740/HAS/ARJSS/7.2/252-262 & Visit us : www.researchjournal.co.in \\
\hline
\end{tabular}

\title{
Relationship of social and emotional skills with stress among adolescents
}

Renu Bala

Department of Human Development Family Studies, C.C.S. Haryana Agricultural University, HISSAR (HARYANA) INDIA

\section{ARTICLE INFO :}

$\begin{array}{lll}\text { Received } & : & 28.09 .2016 \\ \text { Revised } & : & 09.11 .2016 \\ \text { Accepted } & : & 22.11 .2016\end{array}$

KEY WORDS :

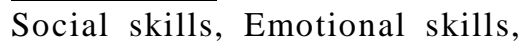
Adolescents, Academic achievement, Mass media

\section{HOW TO CITE THIS ARTICLE :}

Bala, Renu (2016). Relationship of social and emotional skills with stress among adolescents. Adv. Res. J. Soc. Sci., 7 (2): 252-262, DOI: 10.15740/HAS/ARJSS/ 7.2/252-262.

\section{ABSTRACT}

The study was conducted purposively in Haryana state and Delhi. Two institutions were selected purposively. Therefore, from the two institutions, Haryana and Delhi, list of children falling in the age group13-19 years was prepared. From institution of Delhi, 100 adolescents equally representing both the sexes i.e. 50 girls and 50 boys were selected on random basis; similar procedure was used to select the institution of Haryana sample. Hence, a total of 200 adolescents constituted the sample for the study to assess the existing social and emotional skills. Two types of variable were considered in the study- the independent and dependent variable. Adolescent personal variables were taken as the independent variables and social and emotional skills of adolescents were taken as dependent variables. Life Skills Assessment Scale (LSAS) developed by Nair et al. (2010) was used to assess the social and emotional skills among the adolescents. Result revealed that it was found that 68.00 per cent boys and 66.00 per cent girls in institute of Delhi had average level of social skills. The data further showed that 22.00 per cent girls and 20.00 per cent boys fall in below average category. In institute of Haryana 80.00 per cent girls and 58.00 per cent boys were in average category and 16.00 per cent boys and 12.00 per cent girls were fall in below average category. Result further reflects that 86.00 per cent girls and 72.00 per cent boys of institute of Delhi were belong to average level. Only, 22.00 per cent boys and 14.00 per cent girls were in below average category. Similar, trend was found in institute of Haryana, where 82.00 per cent girls and 74.00 per cent boys fall in average category. Only 16.00 per cent girls and 14.00 per cent boys fall in below average category. 